\title{
Histology of Quercus ilex roots during infection by Phytophthora cinnamomi
}

\author{
Miguel Ángel Redondo ${ }^{1}$ - Ana Pérez-Sierra ${ }^{2}$ Paloma Abad-Campos ${ }^{3,4}$. \\ Lilian Torres ${ }^{4} \cdot$ Alejandro Solla $^{5} \cdot$ José Reig-Armiñana $^{6} \cdot$ Francisco García-Breijo $^{4,6}$
}

\begin{abstract}
Key message The speed of infection of Quercus ilex by Phytophthora cinnamomi is influenced by the method of inoculation used, and structural changes in the host do not differ depending on whether primary or secondary roots are infected.

Abstract This study aimed to elucidate the infection process of the invasive pathogen Phytophthora cinnamomi on primary and secondary roots of 2-month-old Quercus ilex seedlings. To test if different methods of inoculation lead to different changes in the host caused by the pathogen, the root system of plants was either immersed into a suspension of $P$. cinnamomi zoospores, or placed in direct
\end{abstract}

Miguel Ángel Redondo

miguel.angel.redondo@slu.se

1 Department of Forest Mycology and Plant Pathology, Swedish University of Agricultural Sciences, Uppsala, Sweden

2 Forest Research, Alice Holt Lodge, Farnham, Surrey, UK

3 Instituto Agroforestal Mediterráneo, Universitat Politècnica de València, Valencia, Spain

4 Departamento de Ecosistemas Agroforestales, Escuela Técnica Superior de Ingeniería Agronómica y del Medio Natural, Universitat Politècnica de València, Valencia, Spain

5 Ingeniería Forestal y del Medio Natural, Universidad de Extremadura, Plasencia, Spain

6 Laboratorio de Anatomía Vegetal "Julio Iranzo", Jardí Botànic de la Universitat de València, Valencia, Spain contact with agar plugs colonized by $P$. cinnamomi mycelium. Histology of root sections obtained every $24 \mathrm{~h}$ for 10 days revealed similar changes in the structure of cells and tissues of the host irrespective of the inoculation method used. However, the immersion method resulted in a delay in the colonization of the host, different aerial symptoms, and the formation of different reproductive structures of the pathogen. Emerging secondary and tertiary roots and sites where secondary or tertiary roots were about to emerge were identified as main entry points. Hyphae in the xylem tissues were more frequently found in secondary than in primary roots, but in both types of roots the phloem was the most important pathway of colonization. For the first time in the interaction between $Q$. ilex and P. cinnamomi, transmission electron microscopy was used to describe degradation of the host cell walls, pit penetration and extrahaustorial matrix. Haustoria development during intracellular growth and hyphal aggregations (stromata) caused no damage to the host cell walls indicating hemibiotrophic parasitism.

Keywords Cell structure - Histological alterations · Histopathology $\cdot$ Microscopy $\cdot$ Pathogenesis · Invasive pathogen

\section{Introduction}

Research increasingly points to root health as the key for future sustainability of managed and natural forest ecosystems. Primary roots provide trees with stability and determine the ability of trees to explore deep water. Fine secondary roots, responsible for the majority of absorption of water and nutrients supplied to the crown, are important elements of plant health and are indicators of tree vitality 
(Corcobado et al. 2013; Laliberté et al. 2015; McConnell and Balci 2015). Species of the genus Phytophthora are among the organisms causing most serious damage to fine roots of trees. These fungus-like eukaryotes which are taxonomically classified as oomycetes cause devastating diseases in an extensive range of tree hosts (Tsao 1990). The oomycete Phytophthora cinnamomi is very effective at damaging roots of plants and for this reason causes broad and economically important impacts in forestry, horticulture, and in the nursery industry (Hardham 2005). Based on scientific and economic importance $P$. cinnamomi was recently included in the list of the 10 most relevant oomycetes in molecular plant pathology (Kamoun et al. 2015)

Quercus ilex is the most abundant tree in Spain and one of the commonest tree species in the Mediterranean basin (Ruiz de la Torre 2006). Quercus ilex forests are under serious threat mainly because of the lack of regeneration (Pulido et al. 2013), episodic events of drought (Corcobado et al. 2014) and decline caused by several species of Phytophthora (Corcobado et al. 2010; de Camilo-Alves et al. 2013; Pérez-Sierra et al. 2013). Tree mortality caused by $P$. cinnamomi is especially relevant in the 'dehesa' or 'montado' agro-silvo-pastoral systems, and in forests where this pathogen concurs with other abiotic or biotic stressors (de Camilo-Alves et al. 2013; Corcobado et al. 2014; Linaldeddu et al. 2014).

Seed germination is a critical step in natural forest regeneration processes. In soils infested with $P$. cinnamomi, acorns of $Q$. ilex do not germinate (RodríguezMolina et al. 2002; Martín-García et al. 2015). If acorns escape from infection, seedlings will be exposed to a second challenge coinciding at a time when conditions are most favourable for $P$. cinnamomi infections, i.e. mean maximum temperatures around $25{ }^{\circ} \mathrm{C}$ and soil moisture contents above $30 \%$ vol (Corcobado et al. 2013). At this time of the year, occurring during May in southern Spain, seedlings are about 2 months old, and radicle elongation represents a crucial step for seedling survival (Cubera et al. 2012). Any limitations to the positive geotropic extension of the primary root during germination may have a significant impact on the ability of the tree to tolerate soil drought and compete with herbaceous plants in summer (Cubera et al. 2012). No information about the infection process of the primary roots of $Q$. ilex trees by $P$. cinnamomi at this critical age is available in the literature.

Artificial inoculations of young trees with Phytophthora spp. performed under controlled conditions have allowed scientists to describe functional and structural changes of woody plants occurring during the infection process (Blaschke 1994; Brummer et al. 2002; Oh and Hansen 2007; Horta et al. 2010; Rytkönen et al. 2013; Dalio et al. 2014; Oßwald et al. 2014). Particularly in holm oak
(Quercus ilex), P. cinnamomi is able to trigger a generalized dysfunction in water relations of seedlings (Robin et al. 2001). The reduction of stomatal conductance of $Q$. ilex seedlings after infection by $P$. cinnamomi may result from changes in concentrations of hormones in host tissues which would be responsible for stomatal closure (Cahill et al. 1986; Robin et al. 2001). Reduction of predawn water potential of $Q$. ilex leaves could be caused by water stress resulting from root loss (Maurel et al. 2001; Robin et al. 2001). Besides altering water relations, $P$. cinnamomi is able to reduce $\mathrm{N}$ and $\mathrm{P}$ contents of leaves and modify the performance of $Q$. ilex seedlings after infection (Maurel et al. 2001; Pérez-Sierra et al. 2013; Corcobado et al. 2014).

Histology of secondary roots of 6-month-old $Q$. ilex seedlings revealed alterations of the structure of the tissues when trees were inoculated with P. cinnamomi (RuizGómez et al. 2012, 2015). Changes in the host included cell wall thickening, an increase in the number and size of intercellular spaces in the central cylinder, accumulation of phenolic compounds in the middle lamella and of pectic substances which sealed pits of the xylem vessels, and the formation of lignitubers (Ruiz Gómez et al. 2015). Lignitubers have been recently described as structures in response to $P$. cinnamomi infection able to isolate cells from penetrating hyphae, even though these encasements alone do not prevent colonization of the host by the pathogen (Crone et al. 2013a; Jung et al. 2013). Structures of the pathogen included chlamydospores forming inside the cortex cells, and stromata within the vascular cylinder (Ruiz Gómez et al. 2015). Stromata are hyphae which aggregate randomly inside the host (Willetts 1997) and are thought to be involved in the long-term survival of $P$. cinnamomi in natural environments (Crone et al. 2013a, b; Jung et al. 2013). Haustoria, i.e. specialized hyphae capable of penetrating the host cell and absorbing nutrients from the host cytoplasm, were not confirmed in secondary roots of $Q$. ilex infected by $P$. cinnamomi (Ruiz-Gómez et al. 2012). The authors suggested further electronic microscopy studies to better characterize these structures. In the present work, different microscopy techniques (including electronic microscopy) were used to study primary and secondary roots of $Q$. ilex seedlings after being inoculated with $P$. cinnamomi by two methods: root immersion into a suspension of motile zoospores and direct contact of $P$. cinnamomi mycelium with the roots. It was hypothesized that (1) different methods of $P$. cinnamomi inoculation will lead to different changes in the host caused by the pathogen, (2) different inoculation methods will change the timing of infection, and (3) the anatomic differences between primary and secondary roots will imply differences regarding infection process and structure formation in these two types of roots. 


\section{Materials and methods}

\section{Plant and pathogen material}

All histology assessments were carried out in roots of $Q$. ilex seedlings 2 months after germination (Fig. 1SIa). Acorns were collected directly from the crown of a single tree located in Malpartida de Plasencia, Extremadura, SW Spain $\left(39^{\circ} 58^{\prime} \mathrm{N} 6^{\circ} 5^{\prime} \mathrm{W}, 443 \mathrm{~m}\right.$ above sea level). Seeds were surface-disinfested (5 min under a $10 \% \mathrm{NaCl}$ solution), germinated in individual free-draining containers containing sterile vermiculite $(\mathrm{pH} \approx 7)$ inside a growth chamber at $25{ }^{\circ} \mathrm{C}(60-70 \%$ relative humidity, $12 \mathrm{~h}$ photoperiod $)$ and seedlings were irrigated with sterile water (Horta et al. 2010)

A single A2 mating type isolate of $P$. cinnamomi (PS694) which has been shown to be highly virulent in $Q$. ilex (Pérez-Sierra et al. 2013) was used. The isolate was preserved in the fungal culture collection maintained at the Instituto Agroforestal Mediterráneo, Universitat Politècnica de València (Spain), in sterile soil extract and oatmeal agar slants (Sigma-Aldrich, Steinheim, Germany) at $14{ }^{\circ} \mathrm{C}$ in the dark.

\section{Inoculations}

Inoculations consisted of two different methods, (1) immersion of the root system of seedlings into a liquid containing a suspension of $P$. cinnamomi zoospores, and (2) direct contact of the root system of seedlings with agar plugs colonized by mycelium of $P$. cinnamomi. For the first inoculation method, $1 \mathrm{~L}$ autoclaved glass flasks containing V8 juice agar $\left(2 \mathrm{~g} \mathrm{CaCO}_{3}, 200 \mathrm{~mL}\right.$ Campbell's V8 juice and $15 \mathrm{~g}$ agar in $800 \mathrm{~mL}$ distilled water) were used. Hyphal tips were transferred onto the V8 juice agar surface and allowed to grow for 5 days at $25{ }^{\circ} \mathrm{C}$. Then flasks were filled with non-sterile soil extract (Jung et al. 1999) and incubated for $72 \mathrm{~h}$ at room temperature for sporangia production. To encourage zoospore release, the flasks were cold-shocked at $4{ }^{\circ} \mathrm{C}$ for $30 \mathrm{~min}$. After this period, the liquid suspension was adjusted to approximately $10^{3}$ motile zoospores $\mathrm{mL}^{-1}$ and the whole root system of $Q$. ilex seedlings was immersed into the suspension and incubated for 10 days at $25^{\circ} \mathrm{C}$ (Fig. 1SIb). For non-infected controls, the root system of $Q$. ilex seedlings was immersed in noncolonized V8 medium flasks filled with non-sterile soil extract. Plants of $Q$. ilex do not show substantial changes in their root system even if exposed to waterlogging during 2.5 months (Corcobado et al. 2014).

For the second inoculation method, seedlings were removed from vermiculite and the root system was washed in sterile water. Inoculations were made by placing $2 \mathrm{~cm}^{2}$
V8 agar plugs containing actively growing mycelium in contact with five secondary roots and the primary root at distances of $0.5-1 \mathrm{~cm}$ from their tips (Fig. 1SI c, d) (Horta et al. 2010). For non-infected controls, non-colonized V8 agar plugs were placed in contact with five secondary roots and the primary root. To avoid desiccation, agar plugs and root tips were covered with a cotton ball moistened with sterile water. In total, 20 seedlings per inoculation method were used plus 12 additional non-inoculated seedlings which were used as controls. The whole infection process was maintained at $25^{\circ} \mathrm{C}$, coinciding with the temperature of optimal plant growth and maximum radicle damage of $Q$. ilex by $P$. cinnamomi (Martín-García et al. 2015).

\section{Sampling and microscopy}

Root segments $1-1.5 \mathrm{~cm}$ in length and $1-2 \mathrm{~mm}$ diameter were sampled from primary and secondary roots every $24 \mathrm{~h}$ over 10 days. Each day, two plants per inoculation method were harvested and about 20 necrotic roots segments per plant were sampled. Before necrotic lesions were observable, root segments from about $1 \mathrm{~cm}$ above the root tips were randomly harvested. For pathogen re-isolation segments from the whole root ball were used (see below). Segments were prepared and sectioned differently depending on the microscopy technique used.

For Light Microscopy (LM), samples were fixed with $5 \%$ glutaraldehyde-paraformaldehyde in $0.02 \mathrm{M}$ Phosphate Buffer Saline (PBS) ( $\mathrm{pH} 7.2)$ for $12 \mathrm{~h}$ at $4{ }^{\circ} \mathrm{C}$ (Casano et al. 2011), then rinsed in buffer and later dehydrated in graded series of ethanol and embedded in Spurr's resin (ref. 14300; Electron Microscopy Science, Hatfield, PA, USA) according to manufacturer's instructions (http://www.emsdiasum.com/microscopy/technical/ datasheet/14300.aspx). Semi-thin sections $2 \mu \mathrm{m}$ thick were obtained using a diamond knife DIATOME Histo $45^{\circ}$ (DIATOME, Hatfield, PA, USA) and a Nova LKB Bromma Ultramicrotome. Sections were stained with $0.5 \%$ aqueous toluidine blue and observed under an Olympus Provis AX-70 light microscope (Olympus Corp., Japan). Images were obtained through an Infinity 2 CCD (Lumenera Corp., Ottawa, ON, Canada) digital camera and processed by Lumenera AnalySIS software. In total, 150-200 root segments were examined through LM.

For Fluorescence Microscopy (FM), samples were fixed with formaldehyde (40\%)-glacial acetic acid-ethanol (75\%) (5:5:90 vol) and rehydrated by immersing them in distilled water for $20 \mathrm{~min}$. Fresh sections 25-30 $\mu \mathrm{m}$ thick were obtained with a freezing Leica CM1325 microtome, and then stained with calcofluor white and $10 \mathrm{M} \mathrm{KOH} \mathrm{(1:1}$ vol). An Olympus U-ULS 100 HG epifluorescence system with U-MWU (excitation filter 330-385 nm, dichroic mirror $400 \mathrm{~nm}$, barrier filter $420 \mathrm{~nm}$ ) and U-MWBV 
(excitation filter $400-440 \mathrm{~nm}$, dichroic mirror $455 \mathrm{~nm}$, barrier filter $475 \mathrm{~nm}$ ) cubes was used. Pictures were obtained and processed as indicated above. In total, 40-50 root segments were examined through FM.

For Low-Temperature Scanning Electron Microscopy (LTSEM), samples were fixed and rehydrated as for fluorescence microscopy. Root segments were then frozen with liquid nitrogen, left for sublimation for $15 \mathrm{~min}$ and gold covered for $30 \mathrm{~s}$. Root surface observations were carried out by a JEOL JSM 5410 microscope (JEOL USA Inc, Peabody, MA, USA), and pictures were obtained with an Olympus MegaView III camera and processed by Olympus analySIS getIT software (Olympus Corp., Japan). In total, 40-50 root segments were examined through LTSEM.

For Transmission Electron Microscopy (TEM), samples were fixed as indicated for light microscopy, then washed three times with $0.02 \mathrm{M}$ PBS ( $\mathrm{pH} 7.4)$ for $15 \mathrm{~min}$ and fixed again with $2 \%$ osmium tetroxide $\left(\mathrm{OsO}_{4}\right)$ in $0.01 \mathrm{M} \mathrm{PBS}(\mathrm{pH}$ 7.4) for $2 \mathrm{~h}$ at room temperature. After washing in buffer, samples were dehydrated and embedded as indicated for light microscopy. Ultrathin sections $80 \mathrm{~nm}$ thick were made with a diamond knife (mod. DIATOME ultra $45^{\circ}$; DIATOME, Hatfield, PA, USA), mounted on copper grids of 100 mesh, and then stained with $10 \%$ uranyl acetate and $0.1 \%$ lead citrate using the "Synaptek Grid-Stick Kit" (EMS; http://www.ems-diasum.com/microscopy/technical/data sheet/71175.aspx). Sections were observed at $80 \mathrm{kV}$ under the JEOL JEM-1010 microscope (JEOL USA Inc, Peabody, MA, USA). Images were obtained using an Olympus MegaView III camera and processed by Olympus analySIS getIT software (Olympus Corp., Japan). In total, 40-50 root segments were examined through TEM.

\section{Re-isolation of Phytophthora cinnamomi}

Re-isolation of $P$. cinnamomi was made from roots inoculated by the two methods. One seedling per day and inoculation method was used. The primary root and two or three secondary roots of each seedling were collected, cut into $6 \mathrm{~mm}$ segments, and segments grouped in two clusters of four segments depending if they were proximal or distal from the point of attachment. Over the duration of the experiment about 450 fine root segments were plated in total onto selective CMA-PARBPH agar medium (Pérez-Sierra et al. 2013). After $2-3$ days of incubation at $22{ }^{\circ} \mathrm{C}$ in the dark, the presence of $P$. cinnamomi in these segments was examined.

\section{Results}

Phytophthora cinnamomi was re-isolated with the same success rate (about $50 \%$ ) from the primary and secondary roots, independently of the inoculation method used. Re- isolations of $P$. cinnamomi from the primary root were more successful in distal rather than in proximal segments (70 vs. $34 \%$, respectively). Re-isolation success from secondary root segments, however, was similar in distal and proximal segments (about $50 \%$ ).

Inoculations of seedlings in contact with agar plugs colonized by $P$. cinnamomi produced a faster colonization of plant tissues than inoculations consisting of dipping the roots into a suspension of $P$. cinnamomi zoospores. Figure 1 summarizes the timeline of events observed during infection of $Q$. ilex roots by $P$. cinnamomi. Roots in contact with mycelium showed visible necrosis $24 \mathrm{~h}$ after inoculation whereas roots immersed into the zoospore suspension showed necrosis after 3 days post-inoculation (dpi) (Fig. 1). Furthermore, plants inoculated by the rootmycelium contact showed aerial symptoms earlier than plants inoculated by the dip method (5 and 7 dpi, respectively) and symptoms differed depending on the method (leaf necrosis vs wilting of apical leaves, respectively) (Fig. 3SI). Most abundant necrotic lesions were observed in the fine lateral roots and occasionally in the cell elongation zone of the primary root. $P$. cinnamomi hyphae, root necrosis and aerial symptoms were not observed in the control seedlings (Fig. 2SI).

At 1 dpi, LTSEM images from sections of immersed roots revealed zoospore encystment and germination, and penetration of germinative tubes into the rhizodermis (Fig. 2). At 3 dpi, hyphae colonizing the cortical parenchyma of immersed root sections were observed (Fig. 3a, FM), and at $4 \mathrm{dpi}$ haustorial-like structures (Fig. 3b, FM) and cell collapse in the cortex were first detected (Fig. 3c, LM). At 5 dpi, hyphae reached the phloem and vascular cambium, and phloem degradation started (Fig. 3d, LM). Hyphae in the xylem and cambium degradation were observable after 10 days of infection (Fig. 4, LM).

In roots inoculated by direct mycelium contact, fungal penetration started immediately (Fig. 1), and at 1 dpi hyphae were detected in the cortex (Fig. 5, FM). Regions of secondary and tertiary root emergence were major infection entry points for $P$. cinnamomi (Fig. 6b, LM). Fluorescence microscopy allowed observation of numerous hyphae growing inside parenchyma cells of cortex and their intercellular spaces (Fig. 5a, b, FM). In roots inoculated by direct mycelium contact hyphae were first detected in the xylem 3 dpi (Fig. 6a, LM), together with haustoriallike structures observed in the phloem (Fig. 5c, FM). In secondary roots inoculated by direct mycelium contact hyphae approached the primary root via the vascular tissue (Fig. 6b, LM) and cortex. Within the first days after inoculation, damage in root tissues included collapse of cortex cells at 2 dpi but especially obvious was the degradation of the phloem (3 dpi; Fig. 6c, d, LM). Cambium degradation 


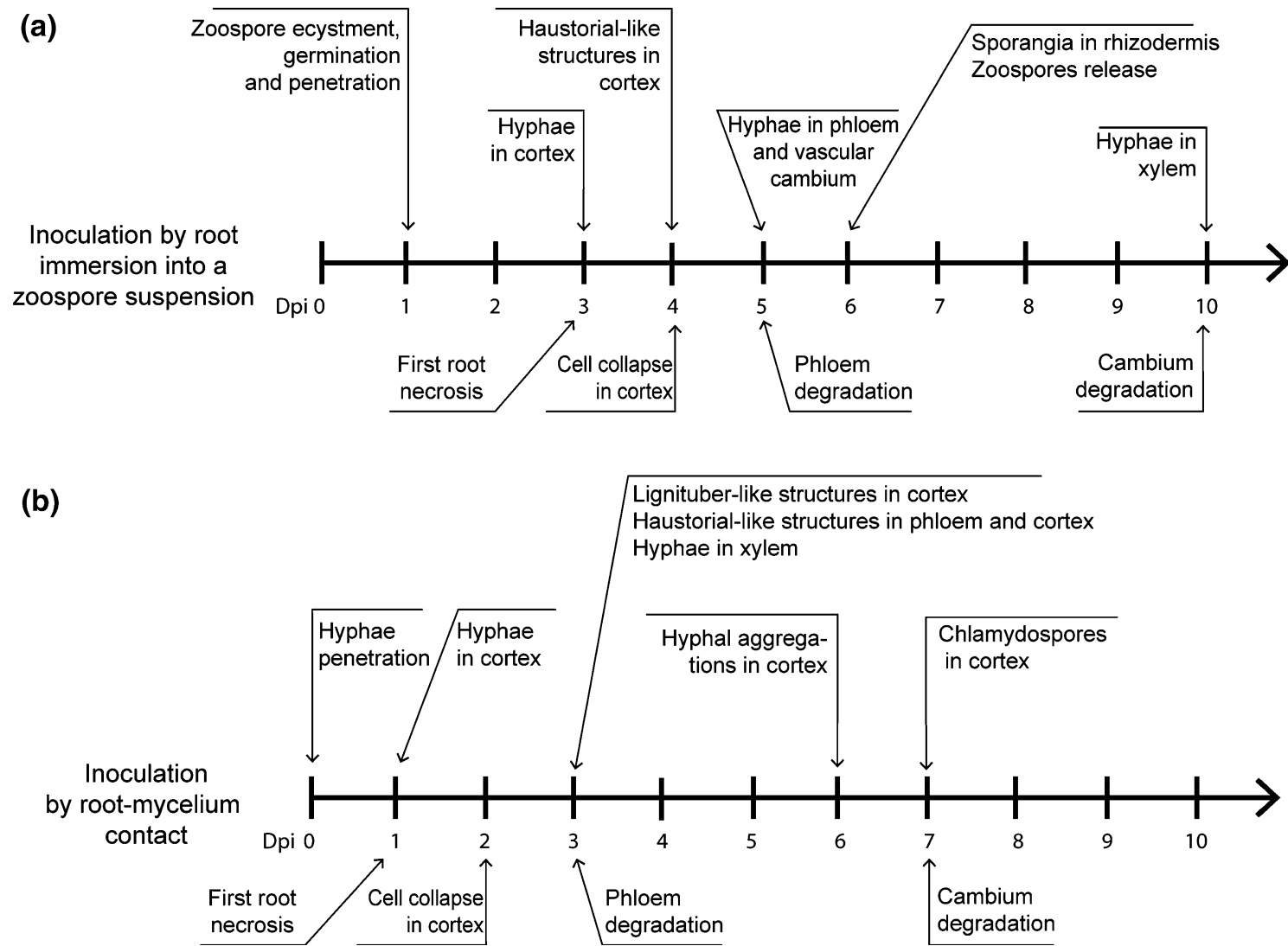

Fig. 1 Sequence of events of early infection of Quercus ilex roots by Phytophthora cinnamomi after inoculation a through root immersion into a zoospore suspension or $\mathbf{b}$ by direct contact of roots with

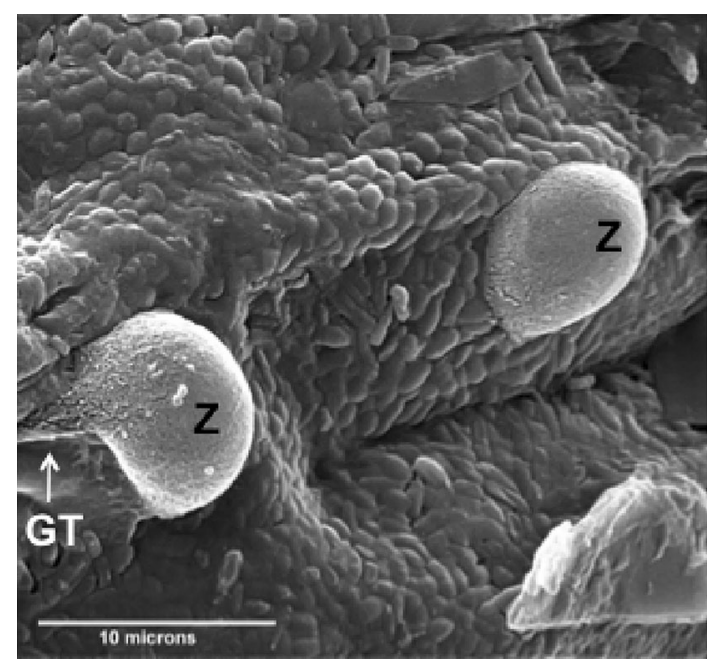

Fig. 2 Low-temperature scanning electron microscopy image showing encystment of Phytophthora cinnamomi zoospores (Z) on a secondary Quercus ilex root $1 \mathrm{dpi}$ via root immersion into a zoospore suspension. On the left side, a germ tube (GT) allows the pathogen to penetrate the rhizodermis. Bar $=10 \mu \mathrm{m}$ mycelium. Above and below the axes pathogen advance and tissue damages are indicated, respectively

started $7 \mathrm{dpi}$, at the time when the phloem cells were completely distorted (Fig. 6d, LM). Even though $P$. cinnamomi hyphae were observed in the xylem, vessels were rarely altered. Interestingly, hyphae in the xylem tissues of primary roots were very scarce in comparison to the abundant hyphae observed in the xylem of secondary roots.

Over the rhizodermis of primary roots inoculated by the dip method, sporangia were observed 6 dpi (Fig. 7a-c, LM). Zoospores released from these sporangia were also observed 6 dpi. Inoculation of seedlings by root-mycelium contact resulted in the formation of hyphal aggregations after 6 days and chlamydospores after 7 days in the cortex of secondary roots (Fig. 7d, LM). Hyphal aggregations were of different shapes but of similar size (Fig. 7e-i, LM). Gametangia or oospores were not observed inside the host.

Ultrathin sections observed in transmission electron microscopy allowed detection of abundant vesicles inside some $P$. cinnamomi hyphae (Fig. 8a, TEM). Electrondense material was observed surrounding hyphae when contacting host cells (Fig. 8b, TEM), surrounding hyphae 

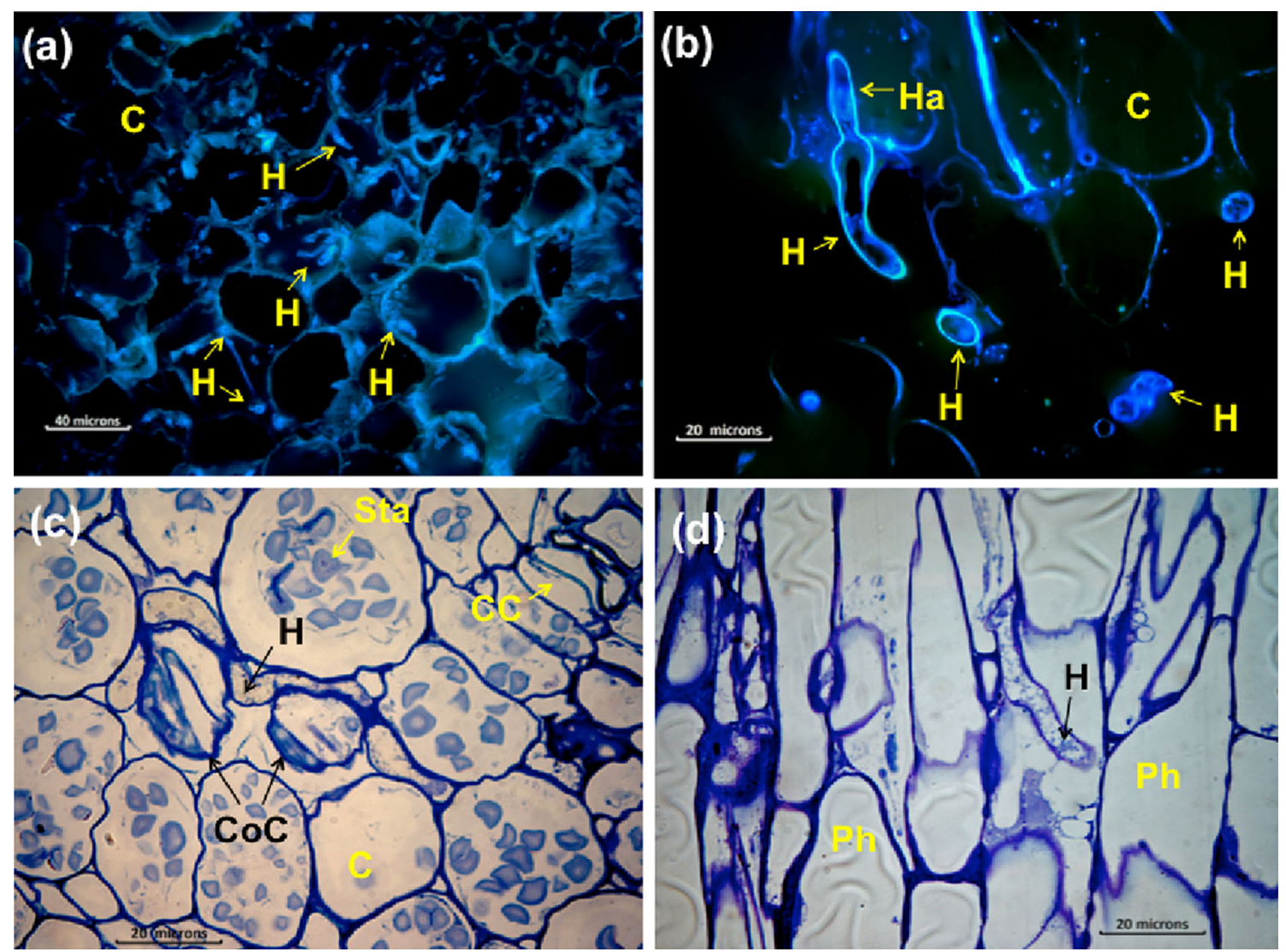

Fig. 3 Fluorescence micrographs $\mathbf{a}, \mathbf{b}$ and light microscopy images $\mathbf{c}$, d of primary and secondary Quercus ilex roots inoculated by immersion into a zoospore suspension of Phytophthora cinnamomi zoospores. Slides were stained with calcofluor white and toluidine blue, respectively. a Cross section of primary root 3 dpi with abundant hyphae $(\mathrm{H})$ growing through the cortical parenchyma $(\mathrm{C})$. Bar $=40 \mu \mathrm{m}$. b Cross section of primary root 4 dpi with hypha

inside host cells (Fig. 8c, TEM) and a papilla was formed at the opposite part of the wall where the hyphae contacted the cell (Fig. 8d, TEM). Electron-dense material depositions were also observed as a matrix around haustorial-like structures when penetrating the host (Fig. 9a-c, TEM), but no extrahaustorial membrane was observed. Interestingly, very little if any electron-dense material was deposited around the hyphal aggregations, and the cell walls of neighbouring cells surrounding the hyphal aggregations did not show degradation (Fig. 7e-i, LM). On the contrary, neighbouring cells surrounding hyphae had their walls degraded (Fig. 8b, c, TEM), and their plasmalemma was frequently detached (Figs. 8d, 9d, TEM). At the entrance points of hyphae penetration, cell walls were strongly degraded by the pathogen (Figs. 9a, b, 10a, b, TEM). Occasionally, $P$. cinnamomi hyphae seemed to oppress the host cell walls (Fig. 9d, TEM) or even folding them at the entrance points (Fig. 10d, TEM). Occasionally, cell wall invaginations surrounded the penetrating hyphae forming a lignituber-like structure (Fig. 9c, TEM).
(H) penetrating a cortical parenchyma cell $(\mathrm{C})$ through a haustoriallike structure (Ha). Bar $=20 \mu \mathrm{m}$. c Cross section of primary root 4 dpi with hypha $(\mathrm{H})$ growing beyond the cork cambium $(\mathrm{CC})$ in the intercellular spaces of the secondary cortex (C), and causing cellular collapses $(\mathrm{CoC})$. Sta $=$ starch. Bar $=20 \mu \mathrm{m}$. d Longitudinal section of a primary root 5 dpi with hypha $(\mathrm{H})$ perforating a phloem cell $(\mathrm{Ph})$. Bar $=20 \mu \mathrm{m}$

\section{Discussion}

Within 10 days of infection P. cinnamomi was able to colonize all tissues of the primary and the secondary roots of 2-month-old $Q$. ilex seedlings. Except for the xylem, severe alteration of the structure of cells was observed in the cortex, phloem and vascular cambium tissues independent of the inoculation method used. The lignin-based composition of the secondary walls of the xylem may explain why the xylem is so resistant to $P$. cinnamomi and other microorganisms (Hatakka 2005). Damage was particularly noticeable in the less lignified but more nutrientrich phloem as reported in previous studies (Oh and Hansen 2007).

Based on results, different methods of $P$. cinnamomi inoculation lead to similar changes in $Q$. ilex tissues. However, the method of inoculation used influenced the speed of the infection process and the type of aerial symptoms and asexual spores produced. It should be acknowledged that differences in the maintenance of plants 


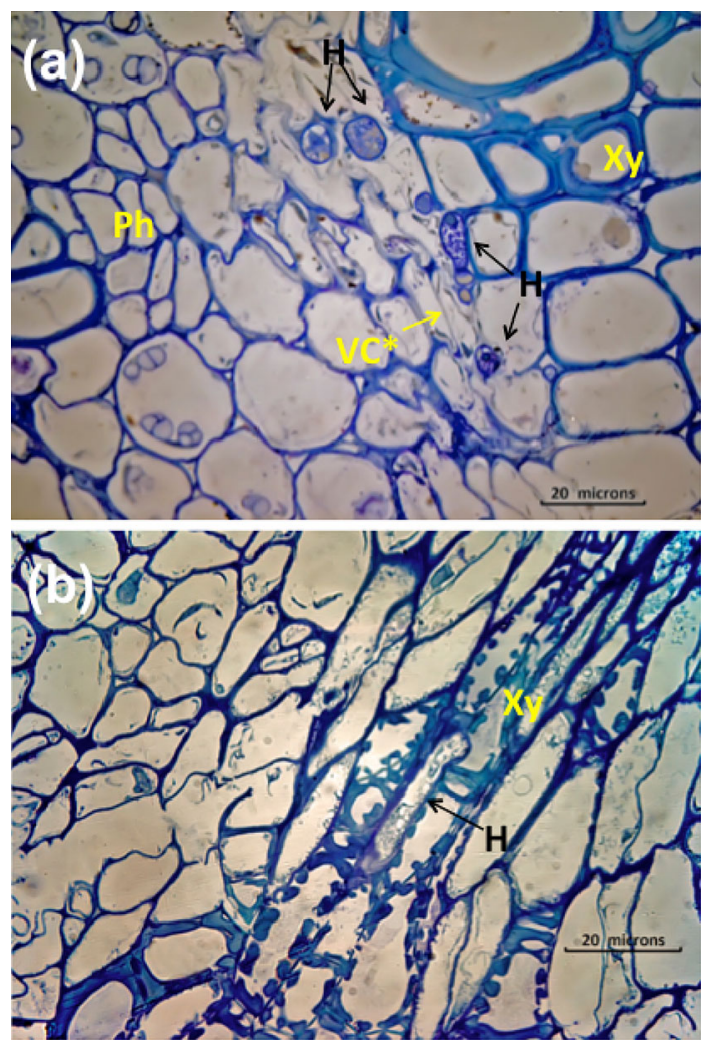

Fig. 4 Light microscopy sections of Quercus ilex primary roots inoculated by immersion into a suspension of Phytophthora cinnamomi zoospores. Slides were stained with toluidine blue. a Cross section 10 dpi with hyphae $(\mathrm{H})$ growing through the vascular cambium and phloem $(\mathrm{Ph})$, causing cellular collapse and cell degradation in the vascular cambium ( $\left.\mathrm{VC}^{*}\right) . \quad X y=x y l e m$. Bar $=20 \mu \mathrm{m}$. b Longitudinal section 10 dpi with a hypha $(\mathrm{H})$ growing through the xylem vessels (Xy). No damage in the xylem was observed. Bar $=20 \mu \mathrm{m}$

between the two inoculation methods used might have influenced the results. Nevertheless, previous research showed that depending on the inoculation method, the symptoms shown by seedlings and their final mortality differed significantly (Hansen et al. 2005; Haque and Diez 2012; Rytkönen et al. 2013). Each host may show a different infection process (Cahill et al. 1989) depending on the species of Phytophthora and the inoculation method used, as indicated by the significant Phytophthora spp. $\times$ inoculation method interaction reported by Haque and Diez (2012). Using the dip method with a suspension of $P$. cinnamomi chlamydospores, at 3 dpi all tissues of secondary $Q$. ilex roots were colonized, but first aerial symptoms consisted of leaf discolouration by $14 \mathrm{dpi}$ (Ruiz Gómez et al. 2015). Root dip into a zoospore suspension mimics the process that occurs in nature, probably better than the mycelium-root contact method. In a leaf inoculation study, higher infection rates and more real symptoms occurred using a zoospore suspension as an inoculum
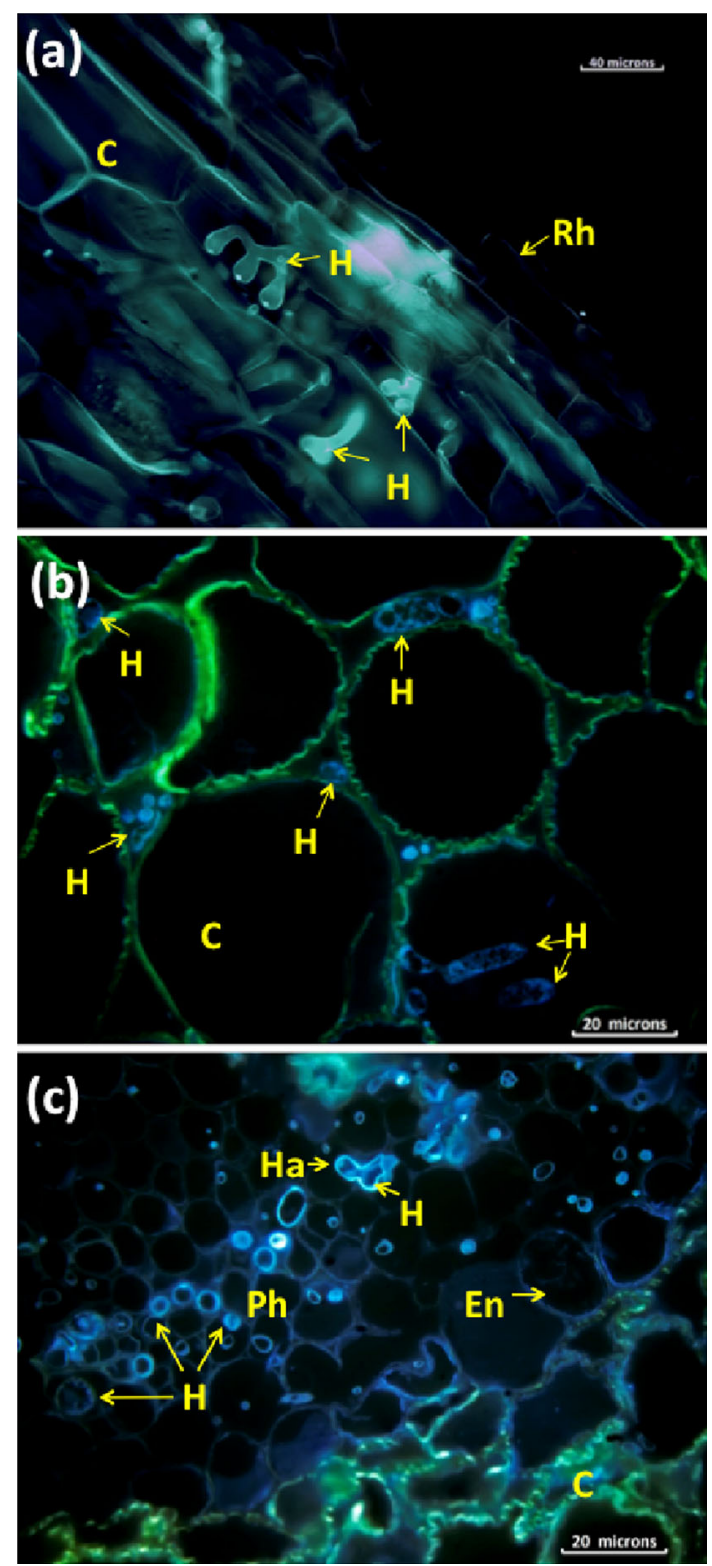

Fig. 5 Fluorescence micrographs of Quercus ilex secondary roots inoculated by direct contact of mycelium of Phytophthora cinnamomi. Slides were stained with calcofluor white. a Longitudinal section 1 dpi showing hyphae $(\mathrm{H})$ growing through cortical cells $(\mathrm{C})$. $R h=$ rhizodermis. Bar $=40 \mu \mathrm{m}$. b Cross section 3 dpi showing hyphae $(\mathrm{H})$ growing inside cortical parenchyma cells $(\mathrm{C})$ and through intercellular spaces. Bar $=20 \mu \mathrm{m}$. c Cross section 3 dpi showing abundant hyphae $(\mathrm{H})$ growing in the phloem $(\mathrm{Ph})$. A haustorial-like structure (Ha) was also observable. $E n=$ endodermis. $C=$ cortical parenchyma. Bar $=20 \mu \mathrm{m}$

source compared to mycelial agar plugs (Hansen et al. 2005).

Infection started immediately by direct hyphal penetration through the epidermal cells, and occurred after 1 day if zoospores were used. This conformed to results of Rytkönen et al. (2013) but contrasted to other studies reporting 


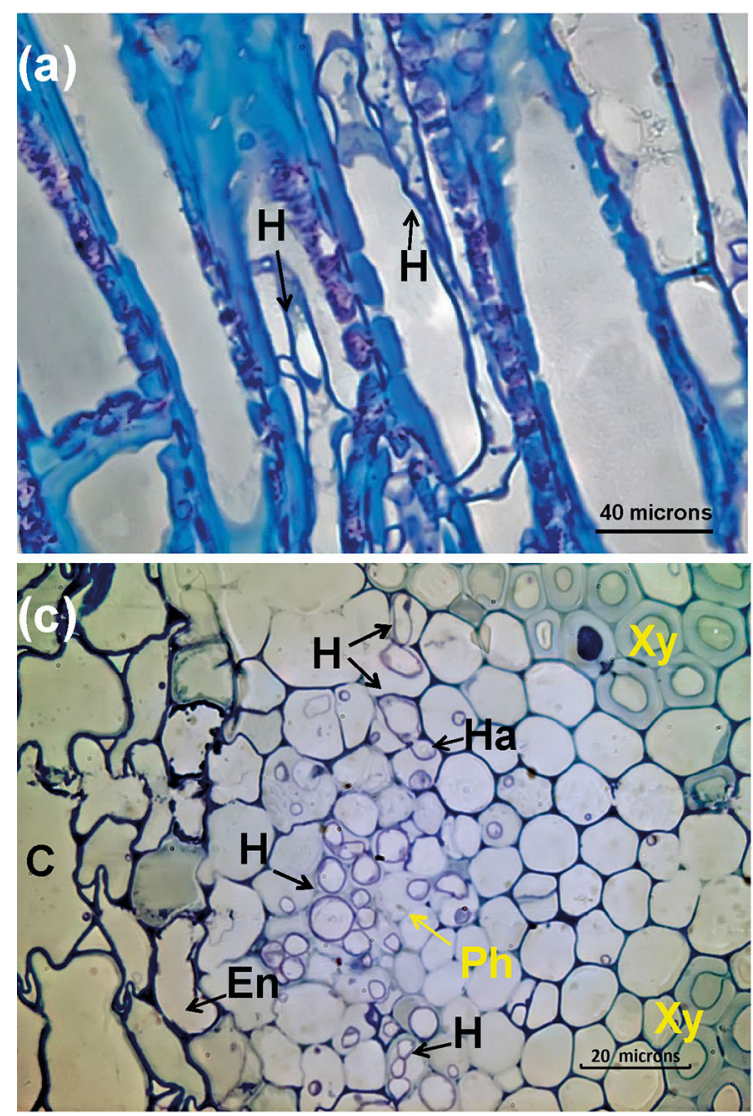

Fig. 6 Light microscopy images of Quercus ilex secondary roots inoculated by direct contact of mycelium of Phytophthora cinnamomi. Slides were stained with toluidine blue. a Longitudinal section 3 dpi with hyphae $(\mathrm{H})$ growing through the xylem (Xy) and no cell damage observed. Bar $=40 \mu \mathrm{m}$. b Detail of a longitudinal section of a lateral root branching point (general view inserted in the upper right) with hyphae $(\mathrm{H})$ growing towards the primary root

immediate penetration of $P$. cinnamomi if zoospores were the source of inoculum (Cahill et al. 1989; Hardham 2005). By immersion of $Q$. ilex roots for 10 min into a chlamydospore suspension $\left(25 \times 10^{3} \mathrm{IU} \mathrm{mL}^{-1}\right)$, infection of secondary roots was also successful 1 dpi (Ruiz-Gómez et al. 2012, 2015). This variation might be due to differences in typology of zoospores suspension and inoculum localization between different studies. In the present work, and in the work performed by Rytkönen et al. (2013), a non-sterile zoospore suspension was used, and the possible presence of bacteria in this suspension during the infection process might affect zoospores survival and infectiveness. In contrast, other work using axenic solutions of zoospores as a source of inoculum reported immediate penetration (Cahill et al. 1989; Hardham 2005). During root segments selection at early stages of infection some of the penetration spots might have been missed because necrotic areas were absent and sample harvesting was performed at random along the root. To avoid the uncertainty of missing

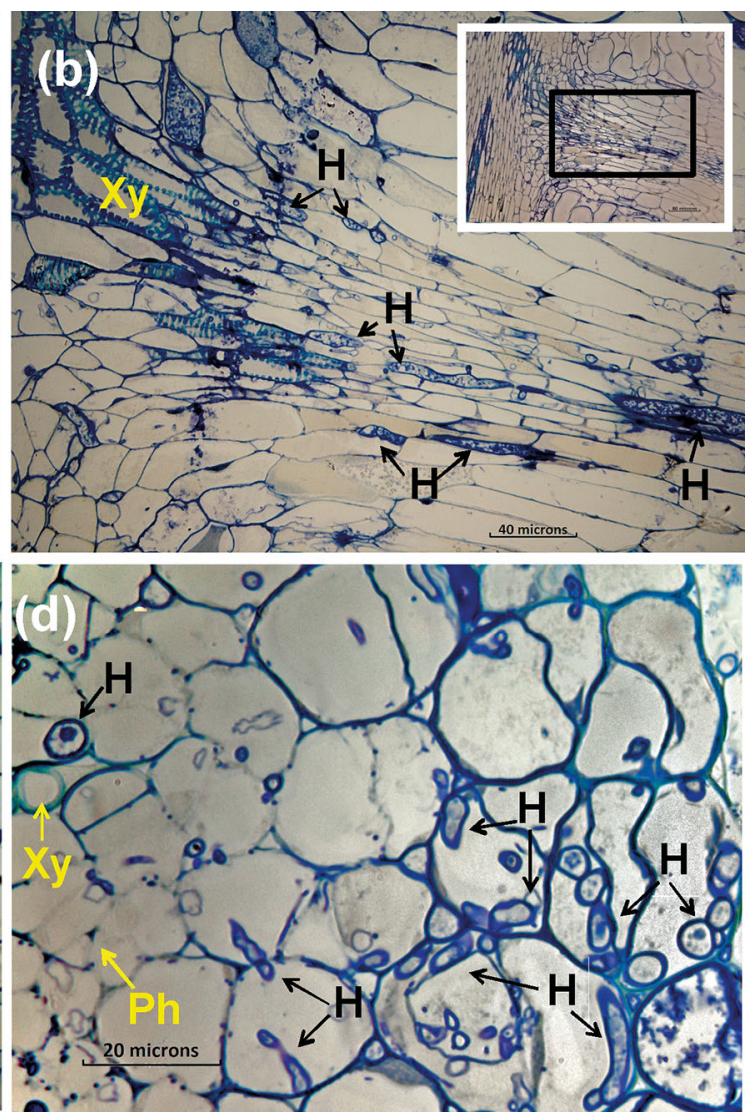

through the vascular tissue. Bar $=40 \mu \mathrm{m}$. c Cross section 3 dpi with many hyphae $(\mathrm{H})$ located inside phloem cells $(\mathrm{Ph})$ causing its degradation. Some haustoria-like structures can be observed (Ha). No hyphae were visible in the cortex (C) and xylem (Xy). En = endodermis. Bar $=20 \mu \mathrm{m}$. d Cross section 7 dpi with abundant hyphae $(\mathrm{H})$ growing through the vascular tissue and endodermis. Completely degraded phloem $(\mathrm{Ph})$ is observable. Bar $=20 \mu \mathrm{m}$

infection sites using zoospore inoculum Cahill et al. (1989) and Hardham (2005) applied the zoospores in well-localized areas, which were later used in the histological studies. No appressoria, reported for other Phytophthora species (Judelson and Blanco 2005; Oh and Hansen 2007), were observed here. Two main infection courts were identified: the emerging secondary or tertiary roots and sites where the developing secondary or tertiary roots were about to emerge. This result could be explained by the fragmentation and discontinuity of tissues in the region immediately surrounding the site of root emergence (Fahn 1990; O'Gara et al. 2015).

Once the epidermis was penetrated, the majority of hyphae observed in the cortical tissue were growing in the intercellular spaces. At this time, extracellular enzymes of Phytophthora may be involved in the degradation of the host cell walls including the middle lamella (Brummer et al. 2002; Hardham 2005). Haustoria developed when intracellular growth occurred, preceded by the 

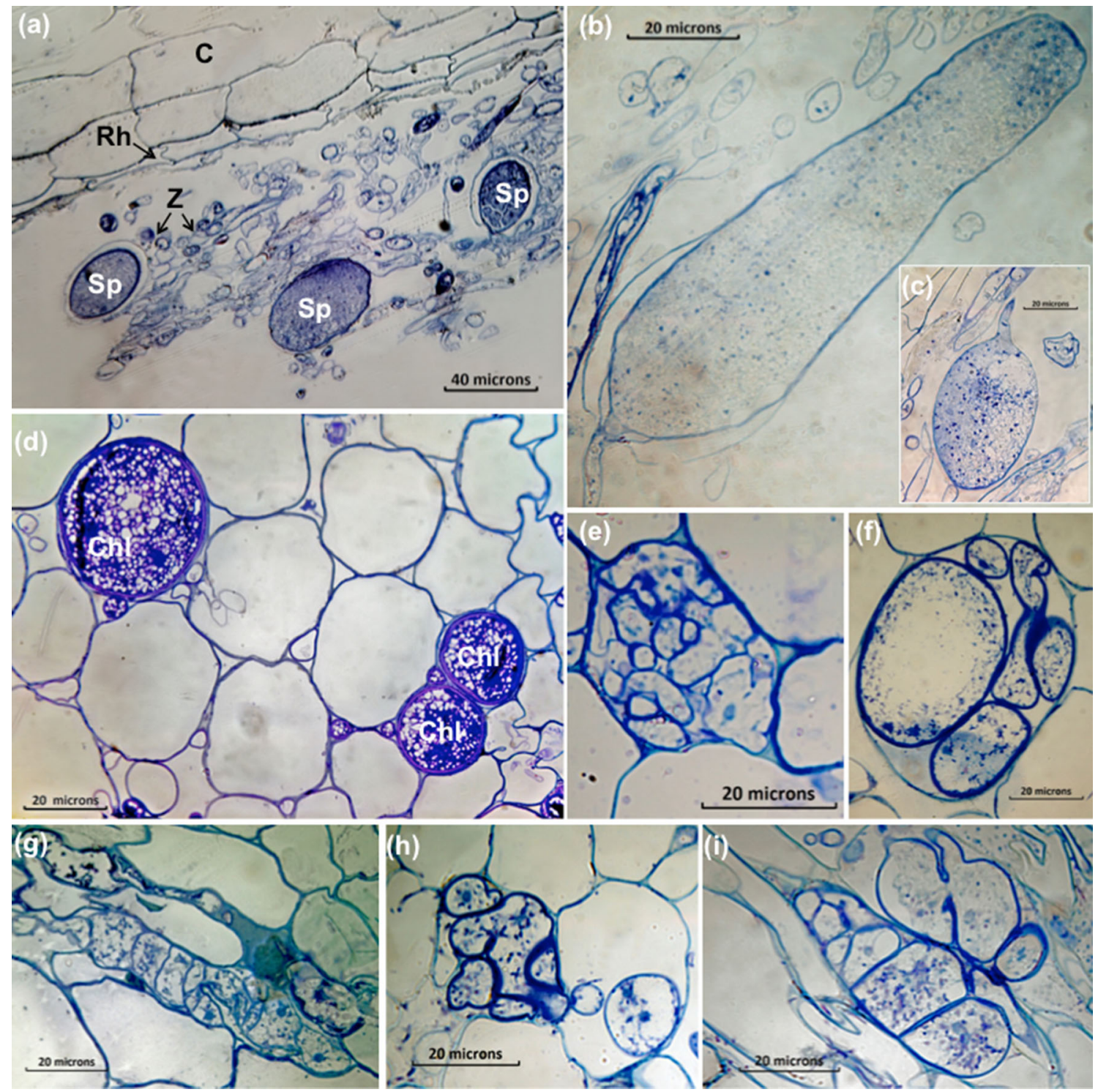

Fig. 7 Light microscopy sections of Phytophthora cinnamomiinfected secondary Quercus ilex roots stained with toluidine blue, in which asexual reproductive and survival structures were observed. a Longitudinal section of immersion-inoculated secondary root section, $6 \mathrm{dpi}$, with several sporangia (Sp) developing on rhizodermis (Rh). Some zoospores $(\mathrm{Z})$ have been released. $C=$ cortex parenchyma. Bar $=40 \mu \mathrm{m}$. b, c Detail of irregular $\mathbf{b}$ and common shaped c sporangia developing on the root surface. Bar $=20 \mu \mathrm{m}$. d Chlamydospores (Chl) developing in the intercellular spaces of cortical parenchyma of mycelia contact inoculated secondary root $7 \mathrm{dpi}$, cross section. Bar $=20 \mu \mathrm{m}$. e, f, g, h, i Hyphal aggregations (stromata) observed 6-10 days after inoculation by the mycelia-root contact method. Bar $=20 \mu \mathrm{m}$

to those in control plants may explain the detachment of the bark from roots, as observed by the authors of this work.

Irrespective of the inoculation method and the type of roots used, 2 days after cortex colonization $P$. cinnamomi hyphae were detected in the phloem. The images confirm that the phloem is the most important pathway for the vertical colonization of $P$. cinnamomi within the plant. Evidence of this movement is shown in Fig. 6b, c where numerous hyphae were detected in the phloem but not in 

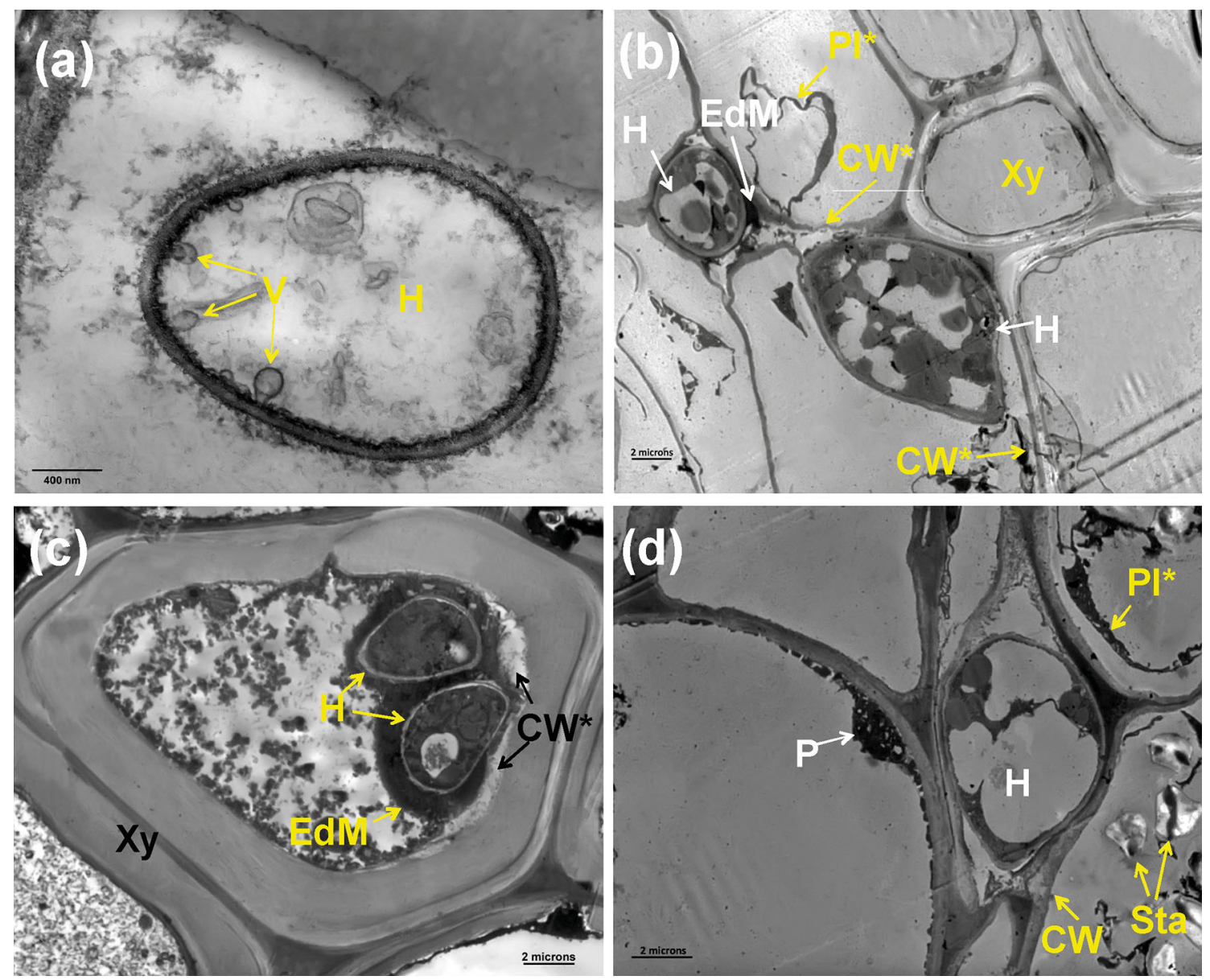

Fig. 8 Transmission electron microscopy examinations of Phytophthora cinnamomi-infected primary and secondary Quercus ilex roots. a Hypha $(\mathrm{H})$ with abundant vesicles (V). Bar $=400 \mathrm{~nm}$. b Hyphae growing in the intercellular spaces $(\mathrm{H})$ and electron-dense material (EdM) deposition surrounding the hyphae. The cell wall close to the hyphae is degraded $\left(\mathrm{CW}^{*}\right)$. $X y=$ xylem. Bar $=2 \mu \mathrm{m}$. c Hyphae (H) inside a xylem vessel (Xy) with electron-dense material (EdM)

the cortex. In consequence, $P$. cinnamomi is able to easily pass through sieve plates connecting sieve elements. Sieve occlusion, usually occurring by callose deposition around the sieve pores within minutes after damage (Mullendore et al. 2010), was not observed to stop phloem colonization by P. cinnamomi (Fig. 3d). Hyphae colonizing the xylem of primary roots were rarely observed, in agreement with previous studies (Brummer et al. 2002; Oh and Hansen 2007), but it was frequent in secondary roots. With the exception of this difference, the infection process did not differ between primary and secondary roots.

Complete destruction of the phloem continued 2 or 3 days after the hyphae first reached this tissue, which confirms observations of infection by other Phytophthora species (Oh and Hansen 2007), and of other hosts infected by $P$. cinnamomi (Cahill et al. 1989). Lignitubers were observed here as a response to $P$. cinnamomi infection and deposition surrounding the hyphae. The cell wall in contact with the hyphae is slightly degraded ( $\left.\mathrm{CW}^{*}\right)$. Bar $=2 \mu \mathrm{m}$. d Hyphae growing in the intercellular space $(\mathrm{H})$, and electron-dense material as a papilla (P) is deposited in the opposite part of the cell wall. Neighbouring cell plasmalemma is detached $\left(\mathrm{Pl}^{*}\right) . C W=$ cell wall. Sta $=$ starch. Bar $=2 \mu \mathrm{m}$

are known to form as a general plant response to isolate cells from penetrating hyphae even though these encasements alone do not completely prevent infection (Crone et al. 2013a; Jung et al. 2013). Tyloses were not detected in accordance to Ruiz Gómez et al. (2015) but in contrast to other studies (Cahill et al. 1989; Blaschke 1994). If occurring, tyloses in $Q$. ilex may form in response to $P$. cinnamomi after 10 days of infection.

Five days after penetration, $P$. cinnamomi produced sporangia in the rhizodermis (Fig. 7). On other hosts, sporangia production by $P$. cinnamomi was reported on infected cortex tissue 48-72 h after inoculation (Cahill et al. 1989; Hardham 2005). In secondary roots of 6-month-old $Q$. ilex seedlings inoculated by $P$. cinnamomi, sporangia formation was not reported, but mature chlamydospores were observed in the cortex 14 dpi (RuizGómez et al. 2012, 2015). Differences in timing of asexual 

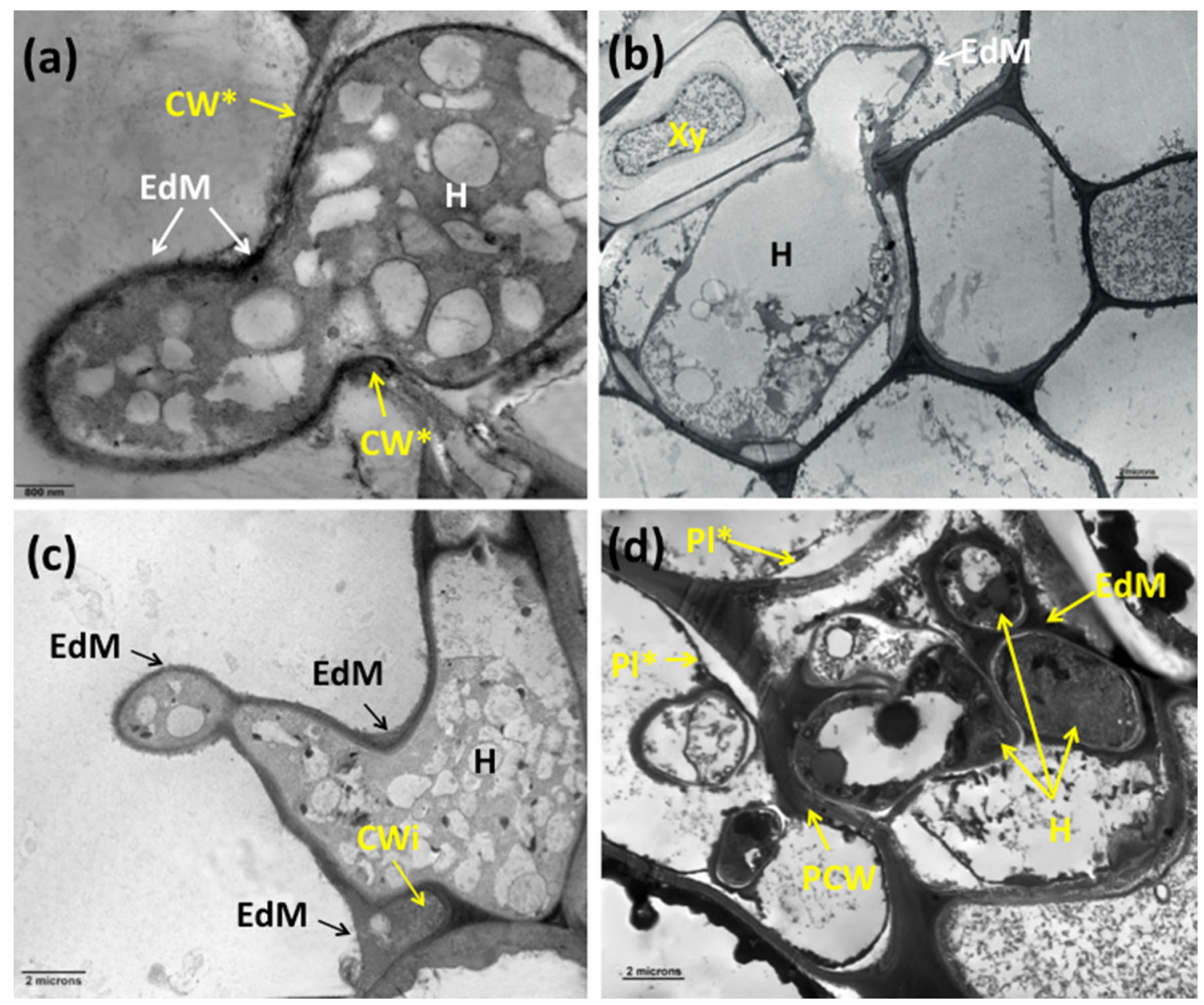

Fig. 9 Transmission electron microscopy examinations of Phytophthora cinnamomi-infected Quercus ilex roots. a Hypha in the intercellular space $(\mathrm{H})$ penetrating a host cell. At the entrance point the cell wall is degraded $\left(\mathrm{CW}^{*}\right)$ and extrahaustorial matrix of electron-dense material was deposited (EdM) around the hypha $(\mathrm{H})$. Bar $=800 \mathrm{~nm}$. b Hypha $(\mathrm{H})$ moving from a protoxylem cell to another $(\mathrm{H}) . B a r=2 \mu \mathrm{m}$. $\mathbf{c}$ Hypha growing in the intercellular space $(\mathrm{H})$ and penetrating a host cell $(\mathrm{H})$. Cell wall invagination as a

spore formation between studies may occur due to differences in host species, type of root, and method of inoculation used, and probably the temperature, age of tissues and concentration of infective units, all of which will also contribute to make results not comparable. Usually $24 \mathrm{~h}$ after formation (Thomas Jung, personal communication) sporangia mature and their papillae dissolve allowing release of motile zoospores ready to start new cycles of infection. This rapid cycle, occurring here within 6 days may explain why $P$. cinnamomi is so successful in causing sudden death of adult $Q$. ilex trees during early summer and early autumn in southern Spain and Portugal (de CamiloAlves et al. 2013) and impedes natural regeneration. Numerous cycles of spore formation, rapid infection and fine roots destruction occurring before symptom expression

haustorial encasement or lignituber-like structure (CWi). At the final part of the invagination, the hypha bypass the cell wall and electrondense matrix is deposited (EdM). Bar $=2 \mu \mathrm{m}$. d Three hyphae growing inside a cell $(\mathrm{H})$ and surrounded by abundant electron-dense material (EdM). The one in the left seems to push the wall (PCW) of the neighbouring cell. The plasmalemma of the host cells is detached $\left(\mathrm{Pl}^{*}\right)$. Bar $=2 \mu \mathrm{m}$

explain the difficulties associated with disease management.

Infection process of $Q$. ilex by $P$. cinnamomi at the ultrastructural level has never been described. In the current study, transmission electron microscopy images showed for the first time in the $Q$. ilex- $P$. cinnamomi interaction, plasmalemma detachment and wall degradation of host cells, hyphae penetration through pits, and depositions of electron-dense material as papillae attached to the cell wall or as an extrahaustorial matrix surrounding the penetrating hyphae. Localized reinforcement of the cell wall through deposition of papillae at sites of pathogen detection appears to be a common component of the pattern-triggered immunity of plants (Underwood 2012). The nature of this dense material is unknown (Oßwald et al. 

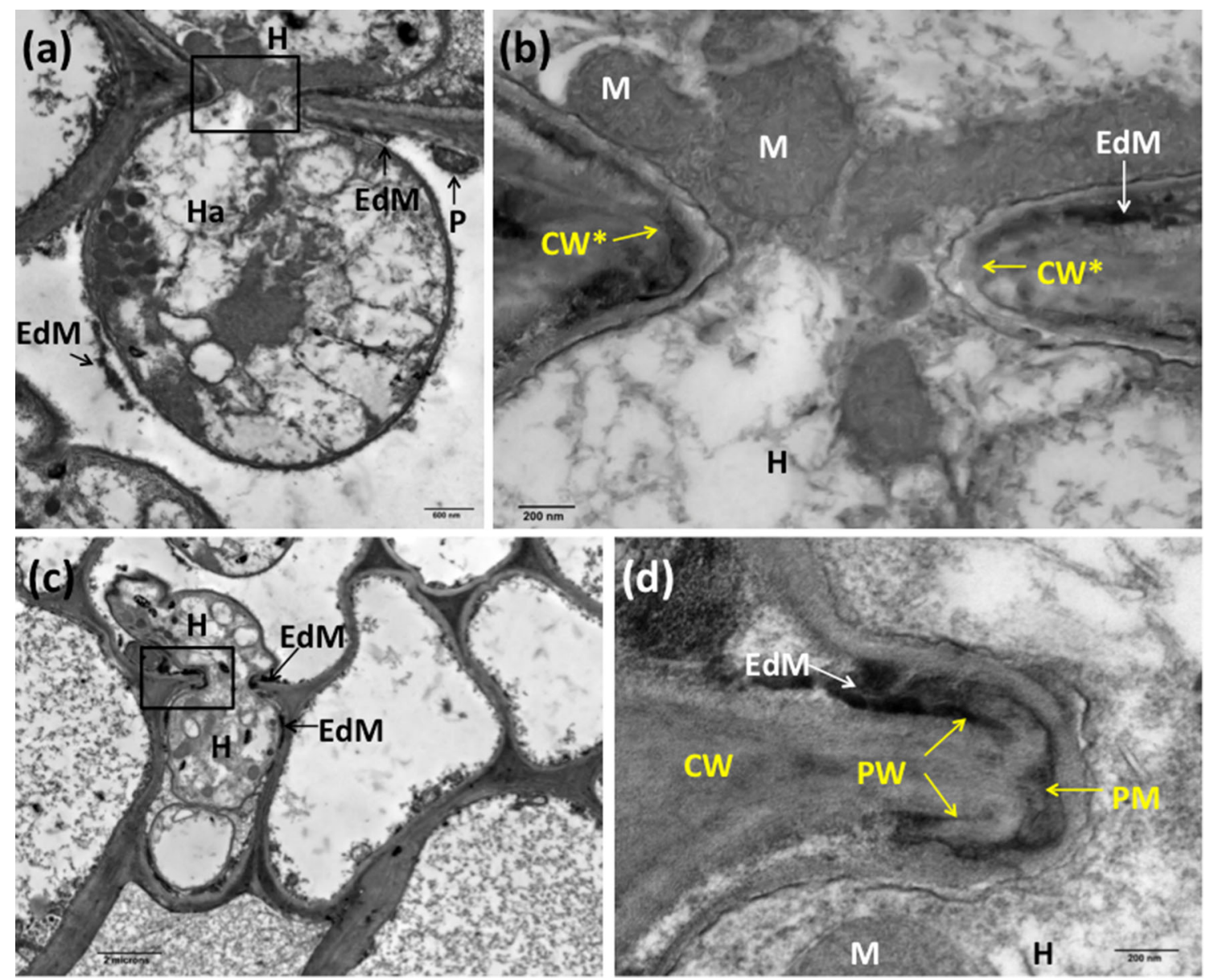

Fig. 10 Transmission electron microscopy examinations of Phytophthora cinnamomi-infected Quercus ilex roots. a Hypha $(\mathrm{H})$ penetrating a host cell and haustorial-like structure $(\mathrm{Ha})$ with electron-dense material depositions (EdM). Electron-dense material is also deposited as a papilla in the inner side of cell wall (P). Bar $=600 \mathrm{~nm}$. b Selective enlargement from (a), showing the entrance point in which the cell wall is degraded $\left(\mathrm{CW}^{*}\right)$, and electron-dense material is

2014) though some authors suggested it is formed by phenolic-like compounds and/or callose (Hardham 2001; Brummer et al. 2002; Horta et al. 2010; Underwood 2012). During later stages of infection, oomycete haustoria are often encased by a double-layered callose-containing membrane structure ( $\mathrm{Lu}$ et al. 2012), not observed here. The vesicles observed inside $P$. cinnamomi hyphae (Fig. 8a) were reported to be involved in the release of cell wall-degrading enzymes by the pathogen (Hardham 2005).

Besides hyphae proliferating through the host tissue, hyphal aggregations varied in density and appearance. These formations called stromata or 'singular stroma' were recently reported in secondary roots of $Q$. ilex (Ruiz Gómez et al. 2015) but are novel in primary roots of this tree species. Typically stromata were confined to one cell, but it was also observed that emerging hyphae penetrated new root cells in close proximity to form more stromata deposited (EdM). Mitochondrion (M). Hyphae (H), Bar $=200 \mathrm{~nm}$. c Hypha $(\mathrm{H})$ penetrating a host cell through a pit. $E d m=$ electrondense material. Bar $=2 \mu \mathrm{m}$. d Selective enlargement from (c), showing the entrance point in which the pit wall appears to be mechanically deformed by the hyphae $(\mathrm{H})$ and folded $(\mathrm{PW})$. These folds expose the pit membrane (PM). Mitochondrion (M). Bar $=200 \mathrm{~nm}$

(Fig. 7h, i) in accordance to what was observed in herbaceous hosts (Crone et al. 2013a). Stromata have been described as morphologically variable formations in regard to size, compactness, and degree of differentiation (Willetts 1997). Functionally, it is suggested that due to the hyphal density of the stromata their capacity to store nutrients acquired from the host material is significant, resulting in the high production of mycelium and spores when conditions are favourable for germination (Willetts 1997). In consequence, stromata act as survival propagules (Willetts 1997; Crone et al. 2013a, b; Jung et al. 2013), and this explains why $P$. cinnamomi is such a persistent pathogen under $Q$. ilex forests. The fact that neighbouring host cells close to stromata did not show damage, necrosis or thickening of walls points to the hypotheses that through these structures the pathogen (1) impedes recognition by the host, (2) suppresses the host's defence gene expression, and 
(3) accumulates nutrients from the host to be invested into the formation of chlamydospores and oospores when conditions become stressful, therefore successfully assuring pathogen persistence.

Haustorium-like structures were not observed in other interactions (Oh and Hansen 2007; Rytkönen et al. 2013), indicating that not all Phytophthora species are hemibiotrophic. The presence of haustoria, i.e. structures involving feeding relationships between the host and the pathogen (Judelson and Blanco 2005), and the formation of numerous chlamydospores indicate that $P$. cinnamomi may temporarily behave as a biotrophic pathogen (Crone et al. 2013a; Ruiz Gómez et al. 2015). It was recently postulated that a necrotrophic mode of $P$. cinnamomi growth would not provide enough nutrients to produce the large numbers of chlamydospores (Crone et al. 2013a). The biotrophic mode of growth with nutrient acquisition aided through haustoria, followed by formation of dense masses of hyphae in stromata may be a prerequisite to the formation of the high numbers of chlamydospores (Crone et al. 2013a).

\section{Conclusions}

Artificial inoculations may not mimic the real interactions between hosts and pathogens in nature. Nevertheless, inoculation methods used under controlled environments may avoid interactions with external variables and make results comparable between experiments. Irrespective of the inoculation method used, similar structural changes in $Q$. ilex roots were observed, although dipping the root system of plants into a zoospore inoculum suspension caused a more delayed colonization, different aboveground symptoms, and the formation of different reproductive structures of the pathogen in comparison to placing the root system of plants in contact to mycelium. This study reports no differences in the initial infection of primary and secondary roots, and provides valuable data of how $P$. cinnamomi colonizes $Q$. ilex at an ontogenic stage critical for tree regeneration. The pathogen rapidly reaches the phloem, which is the most important pathway of vertical colonization of $P$. cinnamomi within the plant. Quercus ilex trees exhibited a variety of directed responses to the pathogen, including general wall thickening, cell collapse, encasement of hyphae, and deposition of electron-dense materials around hyphae. This is the first time transmission electron microscopy has been used to describe cell structures occurring during infection of $Q$. ilex by $P$. cinnamomi. This work will improve further investigation of the pathogenic pathways and survival of $P$. cinnamomi within host tissues, as well as detailed plant pathogenic interactions within the roots. Moreover, results about the timing of production of propagules in fine roots and the time lag between infection and appearance of visible symptoms will be useful for further epidemiological studies.

Author contribution statement Miguel Ángel Redondo: Experiment design, P. cinnamomi inoculation, sampling and histological procedures, elaboration of microscopy images, interpretation of results, and manuscript writing. Ana Pérez-Sierra: Experiment design, $Q$. ilex seedlings growing, P. cinnamomi inoculation and sampling. Paloma Abad-Campos: Experiment design, $P$. cinnamomi inoculation and sampling. Lilian Torres: P. cinnamomi inoculation, sampling and histological procedures. Elaboration of microscopy images, and interpretation of results. Alejandro Solla Acorn: recollection, interpretation of results and manuscript writing. José Reig- Armiñana: Supervision of histological procedures, microscopy images elaboration, and interpretation of results. Francisco García-Breijo: Supervision of histological procedures, supervision of microscopy images elaboration, interpretation of results and manuscript writing.

Acknowledgments This research was financially supported by the Project AGL2011-30438, by the Vicerrectorado de Investigación from the Polytechnic University of Valencia, and by the "Julio Iranzo" laboratory from the Botanic Garden of Valencia. The authors deeply appreciate the help of the staff from both institutions, particularly the valuable contribution of Nuria Cebrián Gómez. Additionally, the staff from the microscopy sections from Polytechnic University of Valencia and University of Valencia have provided us with valuable help. We are grateful to the two anonymous reviewers for the valuable comments in an earlier version of this manuscript.

\section{References}

Blaschke H (1994) Decline symptoms on roots of Quercus robur. Eur J For Pathol 24:386-398. doi:10.1111/j.1439-0329.1994. tb00832.x

Brummer M, Arend M, Fromm J et al (2002) Ultrastructural changes and immunocytochemical localization of the elicitin quercinin in Quercus robur L. roots infected with Phytophthora quercina. Physiol Mol Plant Pathol 61:109-120. doi:10.1006/pmpp.2002. 0419

Cahill DM, Weste GM, Grant BR (1986) Changes in cytokinin concentrations in xylem extrudate following Infection of Eucalyptus marginata Donn ex Sm with Phytophthora cinnamomi Rands. Plant Physiol 81:1103-1109

Cahill D, Legge B, Weste GM (1989) Cellular and histological changes induced by Phytophthora cinnamomi in a group of plant species ranging from fully susceptible to fully resistant. Phytopathology 79:417-424. doi:10.1094/Phyto-79-417

Casano LM, del Campo EM, García-Breijo FJ et al (2011) Two Trebouxia algae with different physiological performances are ever-present in lichen thalli of Ramalina farinacea. Coexistence versus competition? Environ Microbiol 13:806-818. doi:10. 1111/j.1462-2920.2010.02386.x

Corcobado T, Cubera E, Pérez-Sierra A et al (2010) First report of Phytophthora gonapodyides involved in the decline of Quercus ilex in xeric conditions in Spain. New Dis Rep 22:33 
Corcobado T, Cubera E, Moreno G, Solla A (2013) Quercus ilex forests are influenced by annual variations in water table, soil water deficit and fine root loss caused by Phytophthora cinnamomi. Agric For Meteorol 169:92-99. doi:10.1016/j. agrformet.2012.09.017

Corcobado T, Cubera E, Juárez E et al (2014) Drought events determine performance of Quercus ilex seedlings and increase their susceptibility to Phytophthora cinnamomi. Agric For Meteorol 192-193:1-8. doi:10.1016/j.agrformet.2014.02.007

Crone M, McComb JA, O'Brien PA, Hardy GESJ (2013a) Survival of Phytophthora cinnamomi as oospores, stromata, and thickwalled chlamydospores in roots of symptomatic and asymptomatic annual and herbaceous perennial plant species. Fungal Biol 117:112-123. doi:10.1016/j.funbio.2012.12.004

Crone M, McComb JA, O’Brien PA, Hardy GESJ (2013b) Assessment of Australian native annual/herbaceous perennial plant species as asymptomatic or symptomatic hosts of Phytophthora cinnamomi under controlled conditions. For Pathol 43:245-251. doi:10.1111/efp. 12027

Cubera E, Moreno G, Solla A, Madeira M (2012) Root system of Quercus suber L. seedlings in response to herbaceous competition and different watering and fertilisation regimes. Agrofor Syst 85:205-214. doi:10.1007/s10457-012-9492-x

Dalio RJD, Fleischmann F, Humez M, Osswald W (2014) Phosphite protects Fagus sylvatica seedlings towards Phytophthora plurivora via local toxicity, priming and facilitation of pathogen recognition. PLoS One 9:e87860. doi:10.1371/journal.pone.0087860

de Camilo-Alves C, de Sampaio P, da Clara MIE, de Almeida Ribeiro NMC (2013) Decline of mediterranean oak trees and its association with Phytophthora cinnamomi: a review. Eur J For Res 132:411-432. doi:10.1007/s10342-013-0688-z

Fahn A (1990) Plant anatomy. Pergamon Press, Oxford

Hansen EM, Parke JL, Sutton W (2005) Susceptibility of Oregon forest trees and shrubs to Phytophthora ramorum: a comparison of artificial inoculation and natural infection. Plant Dis 89:63-70. doi:10.1094/PD-89-0063

Haque MMU, Diez JJ (2012) Susceptibility of common alder (Alnus glutinosa) seeds and seedlings to Phytophthora alni and other Phytophthora species. For Syst 21:313-322. doi:10.5424/fs/ 2012212-02267

Hardham AR (2001) The cell biology behind Phytophthora pathogenicity. Australas Plant Pathol 30:91-98. doi:10.1071/ AP01006

Hardham AR (2005) Phytophthora cinnamomi. Mol Plant Pathol 6:589-604. doi:10.1111/j.1364-3703.2005.00308.x

Hatakka A (2005) Biodegradation of lignin. Biopolym Online. doi:10. 1002/3527600035.bpol1005

Horta M, Caetano P, Medeira C et al (2010) Involvement of the $\beta$ cinnamomin elicitin in infection and colonisation of cork oak roots by Phytophthora cinnamomi. Eur J Plant Pathol 127:427-436. doi:10.1007/s10658-010-9609-x

Judelson HS, Blanco FA (2005) The spores of Phytophthora: weapons of the plant destroyer. Nat Rev Microbiol 3:47-58. doi:10.1038/nrmicro1064

Jung T, Cooke DEL, Blaschke H et al (1999) Phytophthora quercina sp. nov., causing root rot of European oaks. Mycol Res 103:785-798. doi:10.1017/S0953756298007734

Jung T, Colquhoun IJ, Hardy GESJ (2013) New insights into the survival strategy of the invasive soilborne pathogen Phytophthora cinnamomi in different natural ecosystems in Western Australia. For Pathol 43:266-288. doi:10.1111/efp.12025

Kamoun S, Furzer O, Jones JDG et al (2015) The top 10 oomycete pathogens in molecular plant pathology. Mol Plant Pathol 16:413-434. doi:10.1111/mpp.12190

Laliberté E, Lambers H, Burgess TI, Wright SJ (2015) Phosphorus limitation, soil-borne pathogens and the coexistence of plant species in hyperdiverse forests and shrublands. N Phytol 206:507-521. doi:10.1111/nph.13203

Linaldeddu BT, Scanu B, Maddau L, Franceschini A (2014) Diplodia corticola and Phytophthora cinnamomi: the main pathogens involved in holm oak decline on Caprera Island (Italy). For Pathol 44:191-200. doi:10.1111/efp.12081

Lu Y-J, Schornack S, Spallek T et al (2012) Patterns of plant subcellular responses to successful oomycete infections reveal differences in host cell reprogramming and endocytic trafficking. Cell Microbiol 14:682-697. doi:10.1111/j.1462-5822.2012. 01751.x

Martín-García J, Solla A, Corcobado T et al (2015) Influence of temperature on germination of Quercus ilex in Phytophthora cinnamomi, $P$. gonapodyides, $P$. quercina and $P$. psychrophila infested soils. For Pathol 45:215-223. doi:10.1111/efp.12159

Maurel M, Robin C, Capron G, Desprez-Loustau M-L (2001) Effects of root damage associated with Phytophthora cinnamomi on water relations, biomass accumulation, mineral nutrition and vulnerability to water deficit of five oak and chestnut species. For Pathol 31:353-369. doi:10.1046/j.1439-0329.2001.00258.x

McConnell ME, Balci Y (2015) Fine root dynamics of oak saplings in response to Phytophthora cinnamomi infection under different temperatures and durations. For Pathol 45:155-164. doi:10. 1111/efp. 12150

Mullendore DL, Windt CW, As HV, Knoblauch M (2010) Sieve tube geometry in relation to phloem flow. Plant Cell Online 22:579-593. doi:10.1105/tpc.109.070094

O'Gara E, Howard K, McComb J et al (2015) Penetration of suberized periderm of a woody host by Phytophthora cinnamomi. Plant Pathol 64:207-215. doi:10.1111/ppa.12244

Oh E, Hansen EM (2007) Histopathology of infection and colonization of susceptible and resistant Port-Orford-Cedar by Phytophthora lateralis. Phytopathology 97:684-693. doi:10.1094/ PHYTO-97-6-0684

Oßwald W, Fleischmann F, Rigling D et al (2014) Strategies of attack and defence in woody plant-Phytophthora interactions. For Pathol 44:169-190. doi:10.1111/efp.12096

Pérez-Sierra A, López-García C, León M et al (2013) Previously unrecorded low-temperature Phytophthora species associated with Quercus decline in a Mediterranean forest in eastern Spain. For Pathol 43:331-339. doi:10.1111/efp.12037

Pulido F, McCreary D, Cañellas I et al (2013) Oak regeneration: ecological dynamics and restoration techniques. In: Campos P, Huntsinger L, Oviedo Pro JL (eds) Mediterranean oak woodland working landscapes. Springer, Dordrecht, pp 123-144

Robin C, Capron G, Desprez-Loustau ML (2001) Root infection by Phytophthora cinnamomi in seedlings of three oak species. Plant Pathol 50:708-716. doi:10.1046/j.1365-3059.2001.00643.x

Rodríguez-Molina MC, Torres-Vila LM, Blanco-Santos A et al (2002) Viability of holm and cork oak seedlings from acorns sown in soils naturally infected with Phytophthora cinnamomi. For Pathol 32:365-372. doi:10.1046/j.1439-0329.2002.00297.x

Ruiz de la Torre J (2006) Flora mayor. Organismo Autónomo Parques Nacionales, Dirección General para la Biodiversidad, Madrid

Ruiz Gómez FJ, Navarro-Cerrillo RM, Sánchez-Cuesta R, Pérez-deLuque A (2015) Histopathology of infection and colonization of Quercus ilex fine roots by Phytophthora cinnamomi. Plant Pathol 64:605-616. doi:10.1111/ppa.12310

Ruiz-Gómez FJ, Sánchez-Cuesta R, Navarro-Cerrillo RM, Pérez-deLuque A (2012) A method to quantify infection and colonization of holm oak (Quercus ilex) roots by Phytophthora cinnamomi. Plant Methods 8:39. doi:10.1186/1746-4811-8-39

Rytkönen A, Lilja A, Werres S et al (2013) Infectivity, survival and pathology of Finnish strains of Phytophthora plurivora and $P h$. pini in Norway spruce. Scand J For Res 28:307-318. doi:10. $1080 / 02827581.2012 .756926$ 
Tsao PH (1990) Why many phytophthora root rots and crown rots of tree and horticultural crops remain undetected? EPPO Bull 20:11-17. doi:10.1111/j.1365-2338.1990.tb01174.x

Underwood W (2012) The plant cell wall: a dynamic barrier against pathogen invasion. Front Plant Sci 3:85. doi:10.3389/fpls.2012. 00085
Willetts HJ (1997) Morphology, development and evolution of stromata/sclerotia and macroconidia of the Sclerotiniaceae. Mycol Res 101:939-952. doi:10.1017/S0953756297003559 